Volume 22 , Number

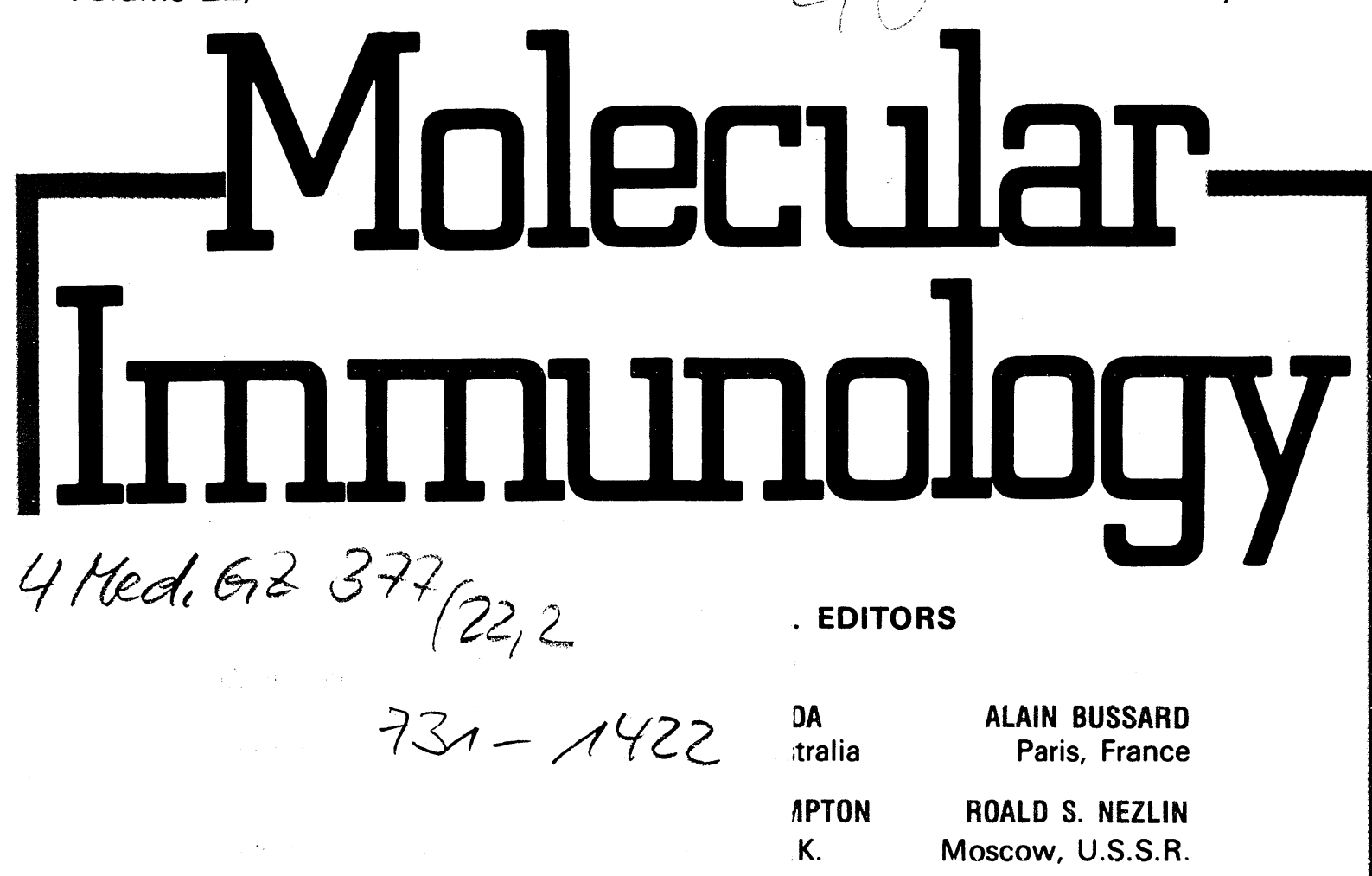

The List of Contents and Author Index for Volume 21, 1984, are inserted loose in this issue

SITTE HIER ABZEICHNEN venn das Heft benutzt wird

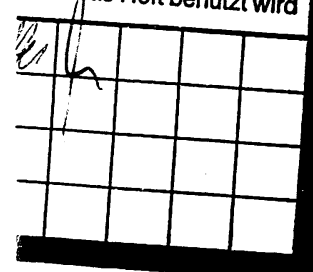

Eingegangen

0 3. JUII 1985

Univ. Bibl. Münctien

Klin Cislihgirin 


\title{
IDENTIFICATION OF MURINE H-2D HISTOCOMPATIBILITY ANTIGENS IN CELLS TRANSFECTED WITH CLONED H-2 GENES
}

\author{
Wilhelm Schmidt, ${ }^{*}$ Janez Ferluga $\dagger$ Hilliard Festenstein $\dagger$ and \\ Elisabeth Weiss+ \\ *Institut für Med. Virologie, Justus-Liebig-Universität Giessen, Frankfurter Str. 107, D-6300 Giessen, \\ F.R.G.; †Department of Immunology. The London Hospital Medical School, Turner Street, London E1 \\ 2AD, U.K.; and ${ }_{+}^{+}$Institut für Immunologie der Universität, Schillerstr. 42, D-8000 München 2, F.R.G.
}

(First received 8 February 1984; accepted in revised form 8 May 1985)

\begin{abstract}
Clones of mouse L-cells transformed with 21 cosmids containing 15 major histocompatibility complex class I genes of C57BL10 $\left(\mathrm{H}-2^{\mathrm{b}}\right)$ sperm cell DNA were analyzed for the expression of their transfected $\mathrm{H}-2$ and $\mathrm{Qa} / \mathrm{Tla}$ genes. Three cosmids contained a single gene, mapping to the H-2D region. This gene encodes the $\mathrm{H}-2 \mathrm{D}^{\mathrm{b}}$ alloantigen: mouse L-cells transfected with cosmids containing this gene reacted with monoclonal antibodies and alloantisera specific for the $\mathrm{H}-2 \mathrm{D}^{\mathrm{b}}$ antigen and expressed a $46-\mathrm{kd}$ $\mathrm{H}-2$ heavy chain associated with $\beta_{2}$-microglobulin in their cell membranes. Furthermore, these transfected cells were stimulators of, and targets for anti-H-2 $\mathrm{D}^{\mathrm{b}}$ cytotoxic $\mathrm{T}$-lymphocytes. Eighteen cosmids contained 14 different genes mapping to the Qa and Tla regions. L-cells transfected with these genes did not express class I genes reacting with alloantisera or monoclonal antibodies against Qa2, Qa4 or TL differentiation antigens. In particular, the Qa2.3 gene of C57BL10 was not identified.
\end{abstract}

\section{INTRODUCTION}

The MHC\$ plays a central role in the regulation of immune responses in mammals. The class I antigens, the polymorphic transplantation antigens initially defined by allograft rejection, and expressed on most somatic cells, are involved in the $\mathrm{T}$-cell recognition of cells altered by viral infection or neoplastic transformation (Zinkernagel and Doherty, 1980).

Both the $\mathrm{H}-2$ class $\mathrm{I}$ antigens and the related $\mathrm{Qa}-$ and TL-antigens are integral membrane glycoproteins of $39,000-45,000 \mathrm{~mol}$. wt and noncovalently associated with $\beta_{2} \mathrm{~m}$ (Nathenson et al., 1981; Vitetta et al., 1975; Michaelson et al., 1981).

Genomic DNA clones from BALB/c and C57BL10 DNA libraries containing MHC class I genes were isolated by recombinant DNA technology (Steinmetz et al., 1982; Mellor et al., 1982). Transformed cells with cloned $\mathrm{H}-2$ genes which express alloantigenic $\mathrm{H}-2$ molecules on their surface have been used for further immunogenetic analysis of the role of MHC antigens in the immune response (Goodenow et al., 1982; Mellor et al., 1982; Margulies et al., 1983).

In this paper we describe the expression and functional properties of a class I gene from the $\mathrm{H}-2 \mathrm{D}$ region of C57BL 10 mice transfected into L-cells. We show that this gene encodes the $\mathrm{H}-2 \mathrm{D}^{\mathrm{b}}$ transplantation antigen.

$\$ M H C$. major histocompatibility complex; $\beta_{2} \mathrm{~m}$. $\beta$,-microglobulin: CTL, cytotoxic T-lymphocyte(s); SDS. sodium dodecylsulfate.

\section{MATERIALS AND METHODS}

Cloning of $\mathrm{H}-2$ genes and establishment of $\mathrm{L}$-cell transformants

The isolation and characterization of genomic clones containing $\mathrm{H}-2$ genes used in this study have been described in detail elsewhere (Weiss et al., 1984). The establishment of stable L-cell transformants was performed as described previously (Mellor et al., 1982). Ltk ${ }^{-}$and transformed L-cells were grown in RPMI medium supplemented with antibiotics and $10 \%$ fetal calf serum.

\section{Mice}

$\mathrm{C} 3 \mathrm{H}, \mathrm{B} 10, \mathrm{~B} 10 . \mathrm{BR}$ and $\mathrm{B} 10 . \mathrm{A}(4 \mathrm{R})$ mice as well as $F$, hybrids were bred in our animal colonies.

\section{Serology}

Complement-dependent cytotoxic tests using monoclonal antibodies and alloantisera were performed as previously described (Schmidt et al., 1981).

Radiobinding studies were done in 96-well microtiter plates. $10^{5}$ cells were incubated with antibody in $50 \mu$ l of RPMI medium plus $10 \%$ foetal calf serum for $1 \mathrm{hr}$ at $4 \mathrm{C}$ on a shaker, washed with MEM and incubated for $30 \mathrm{~min}$ with ${ }^{125} \mathrm{I}$-labelled protein A $(100 \mu \mathrm{Ci} / \mu \mathrm{g})$. Cells were washed 3 times and protein A binding measured in a gamma counter. Alloantisera D2 $\left\{[\mathrm{B} 10 . \mathrm{A}(5 \mathrm{R}) \times \mathrm{LP} . \mathrm{RIII}] \mathrm{F}_{1}\right.$ anti-B10 $\}$, D33 $\left[(\mathrm{B} 10 . \mathrm{D} 2 \times \mathrm{A}) \mathrm{F}_{1}\right.$ anti-B10.A(5R)], and D28.b $[(B 10 . B R \times$ LP.RIII $)$ anti-B10.A(2R)] were obtained from the NIH, Bethesda, MD. Monoclonal antibodies 100-5, 141-30, 166-32, 172-93 and B22-249 
were obtained from $G$. Hämmerling, Heidelberg, F.R.G.; monoclonal antibodies 15-5-5, 20-8-6, 28-8-4 and 28-14-8 were from D. Sachs, Bethesda, MD; D3-262 ascites (anti-Qa2) was from L. Flaherty, New York; anti-TLm4 was from E. A. Boyse. New York; and B16-146 ascites (anti-Qa4) was obtained from Camon Ltd, Wiesbaden, F.R.G. The specificities of these reagents have been described previously (Lemke et al., 1979; Lynes et al., 1982; Ozato et al., 1982; Hämmerling, unpublished; Shen et al., 1982).

\section{Immunoprecipitation and SDS gel electrophoresis}

Cell surface proteins were radiolabelled with ${ }^{125}$ I by the glucose oxidase-lactoperoxidase technique (Hubbard and Colin, 1972) and lysed with $0.5 \%$ NP40 in Tris- $\mathrm{HCl}$ buffer, $\mathrm{pH} 7.4$, containing $0.15 \mathrm{M} \mathrm{NaCl}$, $1 \mathrm{mM} \mathrm{MgCl}$ and $\mathrm{i} 000 \mathrm{KIE} / \mathrm{ml}$ of soy bean trypsin inhibitor. Aliquots of the cell lysates were immunoprecipitated with monoclonal antibodies and alloantisera using Staphylococcus aureus and separated on $12.5 \%$, SDS-polyacrylamide gels as described previously (Schmidt et al., 1981).

\section{Cell-mediated cytotoxicity}

Responder mice were injected once or repeatedly at 14-day intervals with $10^{\circ} \mathrm{B} 10 . \mathrm{A}(4 \mathrm{R})$ lymphocytes or $3 \times 10^{7}$ LB1.1 cells. Fourteen days after the last immunisation the spleen cells $\left(2 \times 10^{7}\right)$ were restimulated in vitro with $10^{7} \mathrm{~B} 10 . \mathrm{A}(4 \mathrm{R})$ lymphocytes irradiated with $(2000 \mathrm{rad})$ or $2 \times 10^{6} \mathrm{LB} 1.1$ cells $(4000$ rad) for 5 days. Cytotoxic activity was assayed in a 4-hr ${ }^{51} \mathrm{Cr}$-release assay using L-cell transformants and PHA-stimulated lymphocytes as targets.

\section{RESULTS}

\section{Cell surface expression of transfected $H-2 D^{h}$ gene}

A cluster of cosmids containing a single $\mathrm{H}-2$ gene was isolated from a DNA library from C57BL10 mouse spleen cells and mapped into the $\mathrm{H}-2 \mathrm{D}$ region of the MHC (Fig. 1) (Flavell et al., 1983).

Mouse L-cells were transformed with cosmids $\mathrm{B} 1.1, \mathrm{~B} 1.1 .1, \mathrm{~B} 1.28$ and $\mathrm{B} 3.2 \mathrm{G}$ by calcium phosphate mediated DNA transfer and selected for stable transformants in HAT medium or in the presence of the G418 antibiotic (Mellor et al., 1982). Transformants LB1.1, LB1.1.1, LB1.28 and LB3.2G obtained with these cosmids respectively reacted in a radiobinding assay with monoclonal antibody against $\mathrm{H}-2 \mathrm{D}^{\mathrm{b}}$ antigens. None of the transformants reacted with monoclonal antibody against $\mathrm{H}-2 \mathrm{~K}^{\mathrm{b}}$ antigens (not shown).
The transformants were further analysed in a radiobinding assay using a panel of monoclonal antibodies, reacting with different epitopes of the $\mathrm{H}-2 \mathrm{D}^{\mathrm{b}}$ antigens and with alloantisera directed against private and public $\mathrm{H}-2^{b}$ specificities. Titrations with monoclonal antibodies directed against different sites of the $\mathrm{H}-2 \mathrm{D}^{\mathrm{b}}$ molecule were performed and established that all epitopes present in $\mathrm{H}-2 \mathrm{D}^{\mathrm{b}}$ alloantigens of B10 lymphocytes (Hämmerling, unpublished results) are present in transformants LB1.1 and LB3.2G. Radiobinding data with a panel of different anti-H $-2^{\mathrm{b}}$ monoclonal antibodies are summarized in Table 1. All antibodies were used at saturating amounts. Ltk ${ }^{-}$cells, LH8 cells transfected with the $\mathrm{H}-2 \mathrm{~K}^{\mathrm{b}}$ gene (not shown) and Lbl.1.1 cells transfected with a Qa-region gene were negative with the anti$\mathrm{H}-2 \mathrm{D}^{\mathrm{b}}$ reagents.

In addition, the transformants reacted with alloantisera D2 (anti-H-2D private specificity) and D28 (anti-H-2D $\mathrm{D}^{\mathrm{b}}$ public specificity) in radiobinding (Table 1) and complement-dependent cytotoxic assay (Table 2). Reactions of the antisera were specific, because pre-absorption with spleen cells from B10 $\left(\mathrm{H}-2^{b}\right)$ mice blocked binding and cytotoxicity whereas absorption with B10.A (H-2k , Qa2,3-positive) did not. There was no reaction of $\mathrm{LB} 1.1$ cells with monoclonal antibodies specific for Qa2 and Qa4 (Table 2).

All transformants continued to express $\mathrm{H}-2 \mathrm{~K}^{\mathrm{k}}$ and $\mathrm{H}-2 \mathrm{D}^{\mathrm{k}}$ antigens.

\section{Expression of class I genes from the Qa/Tla region}

Molecular heterogeneity of the $\mathrm{H}-2 \mathrm{D}$ region products has been reported by Demant et al. (1981). Since the H-2D-region cosmids from C57BL10 DNA only contained a single gene, we investigated L-cells transfected with cosmids carrying genes from the Qa and Tla regions. We attempted to identify the Qa2,3 from C57BL10 (Qa2.3 $\left.{ }^{\mathrm{a}}, \mathrm{Tla}^{\mathrm{b}}\right)$ and to find additional genes reacting with antisera and monoclonal antibodies directed against the $\mathrm{H}-2 \mathrm{D}^{\mathrm{b}}$ antigen.

Table 2 shows the reactivity of $\mathrm{LBl} .11$ cells carrying the Q8 gene from the Qa region. The reaction of this cell line is representative of the other transformants from this cluster. The Qa-specific monoclonal antibodies D3-262 (Qa2) and B16-146 (Qa4) did not react with the transformants.

Table 3 summarizes the reactivity of L-cells transfected with 18 cosmids carrying 14 different class I genes from the Qa and Tla regions (Weiss et al., 1984). None of the cell lines reacted with monoclonal anti-Qa2 and anti-Qa4 antibodies, which were lytic

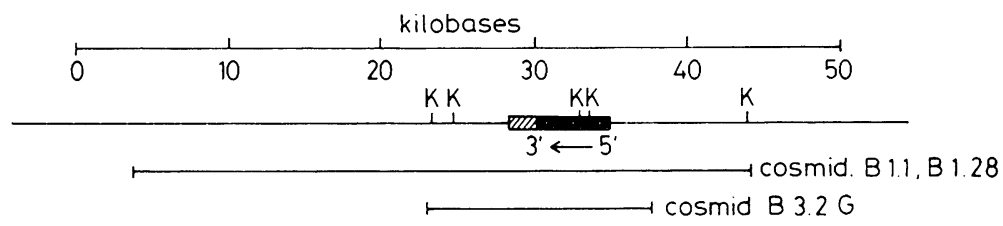

Fig. 1. Physical DNA map of $\mathrm{H}-2 \mathrm{D}^{\mathrm{h}}$ gene deduced from restriction enzyme analysis of cosmids containing the gene. $\mathrm{K}=$ restriction site for KpnI. Orientation of the gene $\left(5^{\prime}\right.$ to $\left.3^{\prime}\right)$ is indicated by the arrow. 
Table 1. Cell surface expression of $H-2 D^{h}$ antigenic sites on $L-c e l l s ~\left(H-2^{k}\right)$ transfected with $H-2 D^{h}$ genes

\begin{tabular}{|c|c|c|c|c|c|c|}
\hline \multirow[b]{4}{*}{ Antibody ${ }^{a}$} & \multirow[b]{4}{*}{ H-2 specificity ${ }^{\prime \prime}$} & \multicolumn{5}{|c|}{$125 \mathrm{I}$-protein $\mathrm{A}$ binding $\left(\Delta \mathrm{cpm} / 10^{5} \text { cells }\right)^{6}$} \\
\hline & & Ltk & LB1.1 & LB3.2G & LBI.1.1 & $\mathrm{B} 10^{d}$ \\
\hline & & \multicolumn{5}{|c|}{ Transfected $\mathrm{H}-2$ gene } \\
\hline & & & $D^{h}$ & $\mathrm{D}^{\mathrm{h}}$ & Qa & -.- \\
\hline \multicolumn{7}{|l|}{ Monoclonal antibody } \\
\hline $100 / 5$ & $\mathrm{~K}^{\mathrm{k}}$ & $143,689 \pm 5724$ & $113.779 \pm 2723$ & $153,023 \pm 891$ & $103,661 \pm 2466$ & $1303 \pm 784$ \\
\hline $15-5-5$ & $D^{k}$ & $45.712 \pm 220$ & $46,718 \pm 482$ & $51,454 \pm 610$ & $45.661 \pm 2243$ & ND \\
\hline $20-8-4$ & $\mathrm{~K}^{\mathrm{h}}$ & $1185 \pm 156$ & $1002 \pm 549$ & $1277 \pm 111$ & $80 \pm 23$ & $81.830 \pm 4025$ \\
\hline $28-8-6$ & $K^{b}, D^{h}$ & $237 \pm 498$ & $27,281 \pm 1898$ & $12.399 \pm 15.52$ & $94 \pm 6$ & $19,400 \pm 71$ \\
\hline $28-14-8$ & $D^{b}$ & $591 \pm 185$ & $105.133 \pm 2126$ & $48,577 \pm 877$ & $36 \pm 151$ & $47,954 \pm 4933$ \\
\hline $141-30$ & $\mathrm{D}^{\mathrm{h}}$ site I & $1502 \pm 405$ & $117.080 \pm 606$ & $: 4,171 \pm 19 ! !$ & ND & $43,308 \pm 1127$ \\
\hline $166-32$ & $\mathrm{D}^{\mathrm{b}}$ site I & $2128 \pm 781$ & $103,418 \pm 3858$ & $44,189 \pm 2392$ & ND & $44,752 \pm 3472$ \\
\hline $172-93$ & $\mathrm{D}^{\mathrm{h}}$ site II & $1716 \pm 328$ & $66,661 \pm 4778$ & $33,281 \pm 2518$ & ND & $17.816 \pm 816$ \\
\hline B22-249 & $\mathrm{D}^{\mathrm{h}}$ site II & $1146 \pm 113$ & $101,355 \pm 4123$ & $44,119 \pm 1965$ & ND & $37.944 \pm 442$ \\
\hline \multicolumn{7}{|l|}{ Antisera } \\
\hline D33 & $K^{b}$ & $1584 \pm 61$ & $1214 \pm 347$ & ND & $2733 \pm 498$ & $64,385 \pm 2960$ \\
\hline D2 & $D^{h}$ & $1323 \pm 441$ & $45,138 \pm 3753$ & ND & $9229 \pm 1544$ & $36,020 \pm 2205$ \\
\hline D2 B10.A absorbed & & ND & $37,865 \pm 3425$ & ND & $N \bar{D}$ & $38,767 \pm 2828$ \\
\hline D2 B10 absorbed & & ND & $3480 \pm 711$ & ND & ND & $3158 \pm 2257$ \\
\hline $\mathrm{D} 28 . \mathrm{b}$ & Public & $430 \pm 143$ & $37,196 \pm 3818$ & ND & $1945 \pm 322$ & $32,269 \pm 2734$ \\
\hline
\end{tabular}

${ }^{a}$ Monoclonal antibodies from either hybridoma culture supernatants or ascites were used at saturating concns; for derivation of reagents see Materials and Methods.

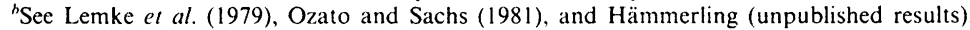

'Normal mouse serum controls (medium: 1008, range: 995 1248) have been subtracted.

${ }^{d} \Delta \mathrm{cpm} / 10^{6}$ cells is given for $\mathrm{B} 10$ binding. 
Table 2. Antibody-dependent cytotoxicity assay of transfected cells

\begin{tabular}{|c|c|c|c|c|c|c|}
\hline \multirow[b]{4}{*}{ Antibody ${ }^{a}$} & \multirow[b]{4}{*}{$\mathrm{H}-2$ specificity } & \multicolumn{5}{|c|}{$\%$ specific ${ }^{51} \mathrm{Cr}$ release ${ }^{h}$} \\
\hline & & \multirow{3}{*}{$\begin{array}{c}\text { Ltk } \\
-\end{array}$} & LBI.I & LB3.2G & LBI.1.1 & $\mathrm{B} 10$ \\
\hline & & & \multicolumn{3}{|c|}{ Transfected $\mathrm{H}-2$ gene } & \\
\hline & & & $\mathrm{D}^{\mathrm{b}}$ & $\mathrm{D}^{\mathrm{b}}$ & $\mathrm{Qa}$ & - \\
\hline \multicolumn{7}{|l|}{ Monoclonal antibody } \\
\hline $100-5$ & $\mathrm{~K}^{\mathrm{k}}$ & 39.9 & 38.0 & 38.2 & 34.0 & 0.3 \\
\hline $20-8-4 s$ & $\mathrm{~K}^{\mathrm{b}}$ & 3.4 & 2.3 & ND & ND & 50.7 \\
\hline $28-14-8 s$ & $\mathrm{D}^{\mathrm{b}}$ & 0.9 & 31.4 & 51.0 & 3.6 & 50.8 \\
\hline D3-262 & Qa2 & 0.4 & 0.8 & 2.6 & 2.1 & 22.7 \\
\hline B16-146 & Qa4 & 0.3 & 0.3 & ND & 0.9 & 39.1 \\
\hline \multicolumn{7}{|l|}{ Antisera } \\
\hline D2 & $\mathrm{D}^{\mathrm{b}}$ & 4.5 & 34.9 & 41.9 & 10.6 & 41.0 \\
\hline D2 B10.A absorbed & & ND & 34.0 & ND & ND & 37.6 \\
\hline D2 B10 absorbed & & ND & 4.6 & ND & ND & 3.4 \\
\hline D28.b & H-2.28 (public) & 9.1 & 33.5 & 47.7 & 1.3 & 43.1 \\
\hline
\end{tabular}

for B10 lymphocytes, as expected, or with anti-TL monoclonal antibody, which was negative for B10 $\left(\mathrm{Tla}^{\mathrm{b}}\right.$ ) but positive for B10.A ( $\mathrm{Tla}^{\mathrm{a}}$ ) thymocytes (not shown). Antiserum D28.b and another anti-H-2.28 serum (ASA30), both of which contained additional anti-Qa2,3 antibodies (Flaherty et al., 1978; Demant and Roos, 1982), also failed to react with L-cells transfected with class I genes from the Qa region. However, all L-cells transfected with Qa-region genes showed a weak reaction with D2 antiserum, which, due to the strain combination used, should not contain anti-Qa2 antibody. This could indicate either a cross-reactivity of the anti- $\mathrm{D}^{\mathrm{b}}$ serum with unidentified class I genes from the Qa region or the presence of additional Qa-reactive antibodies in the serum.

\section{Demonstration of $H-2 D^{h}$ molecules on the cell surface}

L-cells transformed with cosmids B1.1 and B3.2G were cell surface labelled with ${ }^{125}$ I, lysed with NP40 and the cell extracts immunoprecipitated with either alloantisera or monoclonal antibodies directed against the $\mathrm{H}-2 \mathrm{D}^{\mathrm{b}}$ antigen. Immunoprecipitates were analysed by SDS-polyacrylamide gel electrophoresis and the results with transformant LB1.1 are shown in
Fig. 2 (identical results were obtained with B3.2G-transformed L-cells).

The $\mathrm{H}-2 \mathrm{D}^{\mathrm{h}}$-specific alloantisera and the monoclonal antibodies precipitated cell surface polypeptides of mol. wts 11,000 and $46,000, \beta_{2} \mathrm{~m}$ and $\mathrm{H}-2$ heavy chain respectively. The latter comigrated with the $\mathrm{H}-2 \mathrm{D}^{\mathrm{b}}$ heavy chain precipitated from EL4 lysates $\left(\mathrm{H}-2^{\mathrm{b}}\right)$ which were run in parallel on the same gel (not shown). Preabsorption of the anti-H-2 $\mathrm{D}^{\mathrm{b}}$ alloantisera with $\mathrm{B} 10$ prevented precipitation of the $\mathrm{H}-2 \mathrm{D}^{\mathrm{b}}$ heavy chain and the $\beta_{2} \mathrm{~m}$ molecule from LB1.1. Absorption of the anti-H-2 $\mathrm{D}^{\mathrm{b}}$ sera with AKR lymphocytes, to remove antiviral antibodies, or with $\mathrm{B} 10$.A lymphocytes, to remove Qa2,3-reactive antibodies, did not inhibit the precipitation (not shown). No polypeptides were precipitated from LBI.1 cells by anti$\mathrm{H}-2 \mathrm{~K}^{\mathrm{h}}$-specific monoclonal antibodies or antisera. Anti- $\mathrm{H}-2 \mathrm{D}^{\mathrm{b}}$ antibodies and antisera failed to precipitate any polypeptides from untransformed Ltk cells or from L-cells transformed with cosmids containing $\mathrm{H}-2 \mathrm{~K}^{\mathrm{b}}$ (LH8) or Qa genes (LB1.11) (not shown).

\section{Cytotoxic T-cell killing}

To test whether the product of the transfected $\mathrm{H}-2 \mathrm{D}^{\mathrm{b}}$ gene in LBI.1 cells is recognized as a target

Table 3. Reactivity ${ }^{a}$ of L-cells transfected with cosmids containing Qa/Tla genes

\begin{tabular}{|c|c|c|c|c|c|c|c|c|}
\hline \multirow[b]{3}{*}{ Antibody } & \multirow[b]{3}{*}{ Specificity } & \multirow[t]{2}{*}{ Location } & \multicolumn{3}{|c|}{ Qa } & \multicolumn{3}{|c|}{ Tla } \\
\hline & & & Q2,3 & Q6,7 & Q8.9 & $\mathrm{T} 1,2$ & $\mathrm{~T} 3,4,5$ & $\mathrm{~T} 11,12,13$ \\
\hline & & $\begin{array}{l}\text { Class I } \\
\text { gene } \\
\text { Cosmid }\end{array}$ & $\mathrm{H} 26$ & $\begin{array}{c}\text { B2.17 } \\
\text { H16 }\end{array}$ & $\begin{array}{l}\text { B4.8 } \\
\text { H19 }\end{array}$ & $\begin{array}{l}\mathrm{H} 4, \\
\mathrm{H} 13, \\
\mathrm{H} 14\end{array}$ & $\mathrm{H} 9, \mathrm{H} 18$ & $\begin{array}{c}\text { B2.8 } \\
\text { H6. H43 }\end{array}$ \\
\hline $100-5$ & $\mathrm{~K}^{\mathrm{k}}$ & & & ++ & & & ++ & \\
\hline $20-8-4 s$ & $\mathrm{~K}^{\mathrm{h}}$ & & & - & & & - & \\
\hline $28-14-8 \mathrm{~s}$ & $\mathrm{D}^{\mathrm{h}}$ & & & - & & & - & \\
\hline D2 serum & $\mathrm{D}^{\mathrm{b}}$ & & & + & & & ND & \\
\hline D28.b serum & H-2.28 & & & - & & & ND & \\
\hline D3-262 & Qa2 & & & - & & & - & \\
\hline B16-146 & Qa4 & & & - & & & - & \\
\hline TLm4 & TL & & & - & & & - & \\
\hline
\end{tabular}




\section{LB I. I}

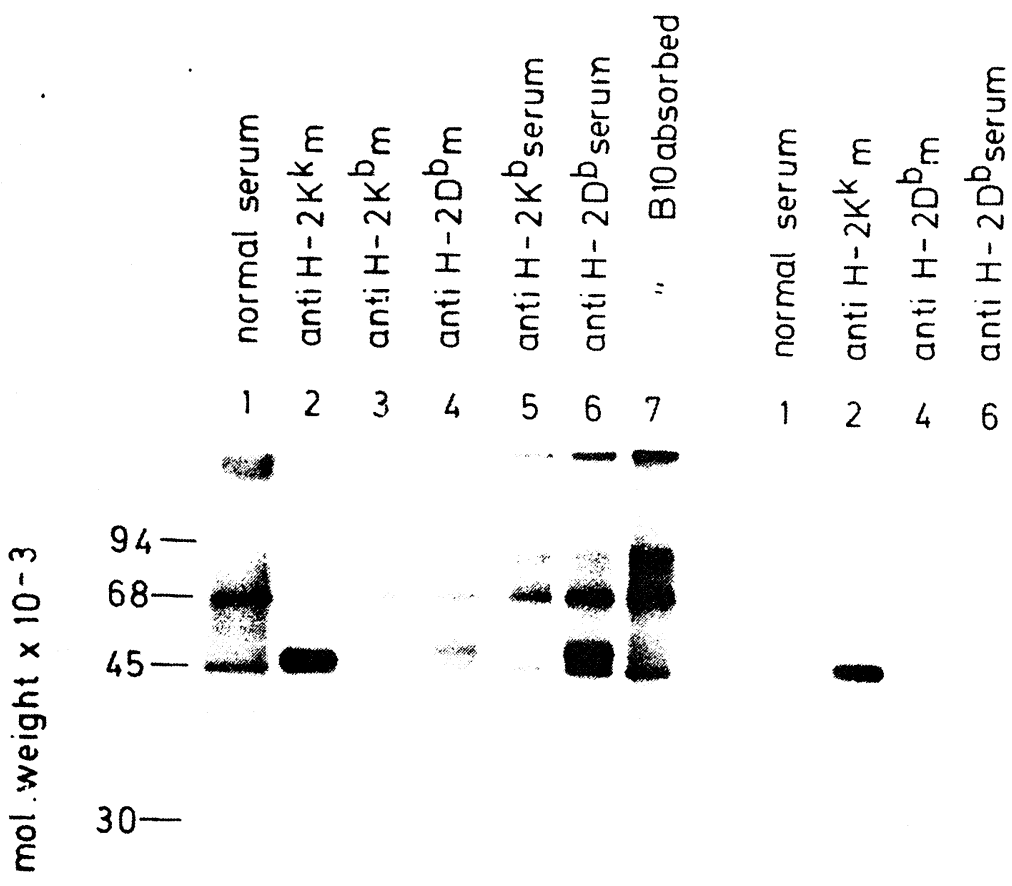

$\mathrm{Ltk}^{-}$$$
6
$$ 
Table 5. Stimulation of anti-H-2D $D^{b}$ cytotoxic lymphocytes by LB1.I cells ${ }^{a}$

\begin{tabular}{|c|c|c|c|c|}
\hline \multirow[b]{2}{*}{ Target cells } & \multirow[b]{2}{*}{ H-2 specificity } & \multicolumn{3}{|c|}{$\begin{array}{c}{ }_{0}^{\circ} \mathrm{Cr} \text { release } \\
\text { (effector:target cell ratio) }\end{array}$} \\
\hline & & $50: 1$ & $16: 1$ & $5: 1$ \\
\hline $\mathrm{C} 3 \mathrm{H}$ & $\mathrm{K}^{k} \mathrm{D}^{k}$ & $13 \pm 1$ & $7 \pm 2$ & $1 \pm 1$ \\
\hline $\mathrm{B} 10$ & $\mathrm{~K}^{\mathrm{b}} \mathrm{D}^{\mathrm{b}}$ & $50 \pm 2$ & $43 \pm 4$ & $28 \pm 3$ \\
\hline $\mathrm{B} \mid 0 . \mathrm{A}(5 \mathrm{R})$ & $\mathrm{K}^{\mathrm{b}} \mathrm{D}^{\mathrm{d}}$ & $21 \pm 1$ & $29 \pm 11$ & $6 \pm 5$ \\
\hline $\mathrm{B} 10 . \mathrm{A}(4 \mathrm{R})$ & $\mathrm{K}^{\mathrm{k}} \mathrm{D}^{\mathrm{b}}$ & $62 \pm 5$ & $50 \pm 6$ & $34 \pm 6$ \\
\hline
\end{tabular}

and expressed by the LB1.1 cells is recognized as target antigen by $\mathrm{H} .2 \mathrm{D}^{\mathrm{b}}$-specific CTL.

We then tested whether the $\mathrm{H}-2 \mathrm{D}^{\mathrm{b}}$ gene product on LB1.1 cells could stimulate anti-H-2 ${ }^{b}$ CTL precursors. We immunized female $\mathrm{C} 3 \mathrm{H}$ mice 4 times by i.p. injection of LB1.1 cells and spleen cells were restimulated in vitro with irradiated LB1.1 cells.

The resultant effector cells lysed B10. and B10.A(4R) target cells (both $\mathrm{H}-2 \mathrm{D}^{\mathrm{b}}$ ), but not B10.A $(5 \mathrm{R})$ targets $\left(\mathrm{H}-2 \mathrm{~K}^{\mathrm{b}}\right)$ (Table 5). These data show that the $\mathrm{H}-2 \mathrm{D}^{\mathrm{b}}$ gene transfected into LBl.1 cells induced $\mathrm{H}-2 \mathrm{D}^{\mathrm{b}}$-specific CTL.

\section{DISCUSSION}

A series of cosmids containing $15 \mathrm{MHC}$ class I genes mapping to the D-, Qa and Tla regions of the $\mathrm{H}-2^{\mathrm{b}}$ genotype have been isolated and transfected into L-cells (Weiss et al., 1984). Only a single gene mapped to the $\mathrm{H}-2 \mathrm{D}$ region. The identity of this gene product with the $\mathrm{H}-2 \mathrm{D}^{\mathrm{b}}$ gene product on $\mathrm{B} 10$ cells was shown by several criteria. (1) L-cells transformed with cosmids containing the gene express a cell surface antigen which carries all antigenic determinants characteristic of the $\mathrm{H}-2 \mathrm{D}^{\mathrm{b}}$ molecule. All epitopes defined by a set of monoclonal antibodies and alloantisera are encoded by the cloned $H-2 D^{b}$ gene. (2) The antigenic determinants are represented on a glycopeptide of $46,000 \mathrm{~mol}$. wt, which can be precipitated by monoclonal antibodies in association with $\beta_{2} \mathrm{~m}$, the invariant polypeptide of all known $\mathrm{MHC}$ class I antigens. (3) The $\mathrm{H}-2 \mathrm{D}^{\mathrm{b}}$ molecules expressed in transformed L-cells can serve as targets for complement-dependent lysis by alloantisera and for allogeneic $\mathrm{H}-2 \mathrm{D}^{\mathrm{b}}$-specific CTL. (4) Transformed Lcells can specifically induce proliferation of $\mathrm{H}$ 2D $\mathrm{D}^{\mathrm{b}}$-specific CTL.

Finally, Townsend et al. (1983) have shown that the gene products of one of the $\mathrm{H}-2 \mathrm{D}^{\mathrm{b}}$ transfectants (LB1.1) acted efficiently as a restriction element for cloned influenza virus specific $\mathrm{H}-2 \mathrm{D}^{\mathrm{b}}$-restricted CTL lines after influenza virus infection of the transformed cells. We have analyzed 14 class I H-2 ${ }^{\text {b }}$ genes which mapped to the Qa or the Tla region (Weiss et al., 1984). Although B10 mice are Qa2,3-positive, we failed to identify the gene(s) coding for the Qa2,3 molecules. These molecules have a limited tissue distribution, and although fibroblasts do not nor- mally express them, the Qa2,3-gene product from $\mathrm{BALB} / \mathrm{c}$ mice was identified after transfer of this gene into L-cells (Goodenow et al., 1982). We were nevertheless able to identify a functional gene in the Qa2.3 region. L-cells transfected with this gene did not react with anti-Qa2 or anti-Qa4 monoclonal antibodies, but could be used to raise antisera which specifically reacted with the transfected cells and with lymphocytes from certain Bl0 congenic mice (Alonzo et al., in preparation).

Restriction mapping of the D-end cosmids failed to reveal an H-2L gene (Weiss et al., 1984), nor could we find an L-molecule on L-cells transfected with D-, Qa or Tla cosmids. This is in agreement with immunogenetic studies (Demant et al., 1981) and in contrast to the findings in $\mathrm{BALB} / \mathrm{c}$ mice, in which 2 additional MHC class I genes have been identified in the $\mathrm{H}-2 \mathrm{D}$ region, 1 of which is the $\mathrm{H}-2 \mathrm{~L}^{\mathrm{d}}$ gene (Goodenow et al., 1982; Winoto et al., 1983). In addition, the genetic basis for $\mathrm{M}$ and $\mathrm{R}$ molecules has not yet been established. Although positive reactions of $\mathrm{H}-2 \mathrm{D}^{\mathrm{b}}$ transfectants were obtained with anti-M and anti- $\mathrm{R}$ antibody (Demant, personal communication), it is not known whether the reactions are directed against the $\mathrm{H}-2 \mathrm{D}^{\mathrm{k}}$ or the $\mathrm{H}-2 \mathrm{D}^{\mathrm{b}}$ molecule. In addition, unexpected reactivities with Qa-region genes were obtained with anti-H-2D ${ }^{\mathrm{h}}$ antisera (Tables 2 and 3).

Furthermore, it is not known whether, due to alternative splicing of the 5 -moiety of certain $\mathrm{H}-2 \mathrm{D}$ transcripts (Transy et al., 1984), there are different-size mRNA transcribed which could generate distinct but antigenically related polypeptides. Further experiments to clarify this point are in progress. In contrast to the $\mathrm{D}$-region, the genetic organisation of the $\mathrm{H}-2 \mathrm{~K}$ region of $\mathrm{C} 57 \mathrm{BL} 10$ and $\mathrm{BALB} / \mathrm{c}$ as well as AKR/J mice is similar (Mellor $e t$ al., 1982; Goodenow et al., 1982; Arnold et al., 1984a).

The transfected $\mathrm{H}-2 \mathrm{D}^{\mathrm{b}}$ gene is biologically active and may thus be used to further elucidate the biological role and the structure-function relationship of this molecule (Zinkernagel et al., 1983). Already several cloned MHC class I genes have been shown to act as restriction elements for specific CTL after transfection into appropriate recipient cells (Örn et al., 1982; Mellor et al., 1982; Levy et al., 1983; Margulies et al., 1983; Townsend et al., 1983). 
Furthermore, the construction of hybrid $\mathrm{H}-2$ genes should help not only to map serological determinants (Evans et al., 1982) but also to define functional domains of the $\mathrm{H}-2$ molecule, such as those involved in interaction with foreign antigens or CTL recognition (Arnold et al., 1984b; Ozato et al., 1983).

The transfer of cloned $\mathrm{H}-2$ genes into tumour cells should help to understand the role of these molecules in tumour growth and metastasis (Hui et al., 1984).

Acknowledgements - We are grateful to Hans Göbler for technical assistance. This work was supported by grants from the Deutsche Forschungsgemeinschaft and the Cancer Research Campaign of Great Britain.

\section{REFERENCES}

Arnold B., Burgert H.-G., Archibald A. L. and Kvist S. (1984a) Complete nucleotide sequence of the murine $\mathrm{H}-2 \mathrm{~K}^{\mathrm{k}}$ gene. Comparison of three $\mathrm{H}-2 \mathrm{~K}$ locus alleles. Nucleic Acid Res. 12, 9473-9487.

Arnold B.. Burgert H.-G., Hamann U., Hämmerling G., Kees U. and Kvist S. (1984b) Cytotoxic T cells recognize two amino-terminal domains of $\mathrm{H}-2 \mathrm{~K}$ antigens in tandem in influenza A infected cells. Cell 38, 79-87.

Demant P., Ivanyi D., Oudshoorn-Snoek M., Calafat J. and Roos M. H. (1981) Molecular heterogeneity of $\mathrm{H}-2$ antigens. Immun. Rev. 60, 5-22.

Demant P. and Roos M. H. (1982) Molecular heterogeneity of D-end products detected by anti $\mathrm{H}-2.28$ sera. I. A molecule similar to Qa2, detected in the BALB/c but not in the $\mathrm{BALB} / \mathrm{c}-\mathrm{H}-2^{\mathrm{dm} 2}$ mutant. Immunogenetics 15 , 46l-466.

Evans G. A., Margulies D. H., Shykind B., Seidman J. G. and Ozato K. (1983) Exon shuffling: mapping polymorphic determinants on hybrid mouse transplantation antigens. Nature, Lond. 300, 755-757.

Fellous M., Kamoun M., Wiels J., Dausset J., Clements G., Zeuthen J. and Klein G. (1977) Induction of HLA expression in Daudi cells after cell fusion. Immunogenetics 5, 423-436.

Flaherty L., Zimmerman D. and Hansen T. H. (1978) Further serological analysis of the Qa antigens. Analysis of an anti-H-2.28 serum. Immunogenetics 6, 245-251.

Flavell R. A., Grosveld F., Busslinger M. et al. (1983) Structure and expression of the human globulin genes and murine histocompatibility antigen genes. Cold Spring Harbor Symp. quant. Biol. 47, 1067-1978.

Goodenow R. S., McMillan M., Nicolson M., Sher B. T., Eakle K., Davidson N. and Hood L. (1982) Identification of the class I gene of the mouse major histocompatibility complex by DNA-mediated gene transfer. Nature, Lond. 300, 231-237.

Hubbard A. L. and Colin Z. A. (1972) The enzymatic iodination of the red cell membrane. J. Cell Biol. 55, 390-405.

Hui K.. Grosveld F. and Festenstein H. (1984) Rejection of transplantable AKR leukaemia cells following MHC DNA-mediated cell transformation. Nature, Lond. 311, $750-752$

Klcin J. (1979) The major histocompatibility complex of the mouse. Science 203, 516-521.

Lemke H., Hämmerling G. J. and Hämmerling U. (1979) Fine specificity analysis with monoclonal antibodies of antigens controlled by the major histocompatibility complex and the Qa/Tla region in mice. Immun. Rev. 47, 175-206.
Levy R. B., Richardson J. C., Margulies D. H., Evans G. A., Seidman J. G. and Ozato K. (1983) The product of transferred $\mathrm{H}-2$ genes express determinants that restrict hapten-specific cytotoxic $\mathrm{T}$ cell. J. Immun. 130, 2514-2518.

Lynes M. A., Tonkonogy S. and Flaherty L. (1982) Qa-1 and Qa-2 expression of CFUs. J. Immun. 129, 928-930.

Margulies D. H., Evans G. A., Ozato K., Camerini-Otero D., Tanaka K., Appella E. and Seidman J. G. (1983) Expression of $\mathrm{H}-2 \mathrm{~K}^{\mathrm{d}}$ and $\mathrm{H}-2 \mathrm{~L}^{\mathrm{d}}$ mouse major histocompatibility antigen genes in $\mathrm{L}$ ce!ls after DNAmediated gene transfer. J. Immun. 130, 463-470.

Mellor A. L., Golden L., Weiss E. et al. (1982) Expression of murine $\mathrm{H}-2 \mathrm{~K}^{\mathrm{b}}$ histocompatibility antigens in cells transformed with cloned H-2 genes. Nature, Lond. 298, 529-534.

Michaelson J., Flaherty L., Bushkin Y. and Yudkowitz H. (1981) Further biochemical data on Qa2. Immunogenetics 4, 129-140.

Nathenson S. G., Uehara H., Ewenstein B. M., Kind T. J. and Coligan J. E. (1981) Primary structural analysis of the transplantation antigens of the murine $\mathrm{H}-2$ major histocompatibility complex. A. Rev. Biochem. 50, 1025-1052.

Örn A., Goodenow R. S., Hood L., Brayton P. R., Woodward J. G., Harmon R. C. and Frelinger J. A. (1982) Product of a transferred $\mathrm{H}-2 \mathrm{~L}^{\mathrm{d}}$ gene acts as restriction element for LCMV-specific killer T cells. Nature, Lond. 297, 415-417.

Ozato K., Evans G. A., Shykind B., Margulies D. and Seidman J. G. (1983) Hybrid H-2 histocompatibility gene products assign domains recognized by alloreactive $\mathrm{T}$ cells. Proc. natn. Acad. Sci. U.S.A. 80, 2040-2043.

Ozato K. and Sachs D. H. (1981) Monoclonal antibodies to mouse MHC antigens. III. Hybridoma antibodies teaching to antigens of the $\mathrm{H}-2^{\mathrm{b}}$ haplotype reveal genetic control of isotype expression. J. Immun. 126, 317-321.

Schmidt W., Leben L., Atfield G. and Festenstein H. (1981) Variation of expression of histocompatibility antigens on tumor cells: absence of $\mathrm{H}-2 \mathrm{~K}^{\mathrm{k}}$ gene products from a Gross virus-induced leukaemia in Balb.K. Immunogenetics 14, 323-339.

Shen F. W., Chorney M. J. and Boyse E. A. (1982) Further polymorphism of the Tla locus defined by monoclonal TL antibodies. Immunogenetics 15, 573-578.

Steinmetz M., Winoto A., Minard K. and Hood L. (1982) Clusters of genes encoding mouse transplantation antigens. Cell 28, 489-498.

Townsend A. R. M., Taylor P. M., Mellor A.. L. and Askonas B. A. (1983) Recognition of $\mathrm{D}^{\mathrm{h}}$ and $\mathrm{K}^{\mathrm{h}}$ gene products by influenza specific cytotoxic $\mathrm{T}$ cells. Immunogenetics 17, 283-294.

Transy C., Lalanne J. L. and Kourilsky P. (1984) Alternative splicing in the $5^{\prime}$ moiety of the $\mathrm{H}-2 \mathrm{~K}^{\mathrm{d}}$ gene transcript. EMBO J. 3, 2383-2386.

Vitetta E. S., Uhr J. W. and Boyse E. A. (1975) Association of $\beta_{2}$-microglobulin-like subunits with $\mathrm{H}-2$ and TL alloantigens on murine thymocytes. J. Immun. 114, 252-254.

Weiss E. H., Golden L., Fahrner K., Mellor A. L., Devlin J. J., Bullman H., Tiddens H., Bud H. and Flavell R. A. (1984) Organization and evolution of the class I gene family in the major histocompatibility complex of the C57BL/10 mouse. Nature, Lond. 310, 650-655.

Winoto A., Steinmetz M. and Hood L. (1983) Genetic mapping in the major histocompatibility complex by restriction enzyme site polymorphisms: most mouse class I genes map to the Tla region. Proc. natn. Acad. Sci. U.S.A. 80, 3425-3439.

Woodward J. G., Örn A., Harmon R. C., Goodenow R. S. Hood L. and Frelinger J. A. (1982) Specific recognition of the product of a transferred major histocompatibility complex gene by cytotoxic T lymphocytes. Proc. natn. Acad. Sci. U.S.A. 79, 3613-3617.

Zinkernagel R. M. and Doherty P. C. (1979) MHC- 
restricted cytotoxic $T$ cells: studies on the biological role of polymorphic major transplantation antigens determining $T$-cell restriction specificity function and responsiveness. Adr. Immun. 27, 51-277.
Zuniga M. C., Malissen B., McMillan M., Brayton P. R.. Clark S. S., Forman J. and Hood L. (1983) Expression and function of transplantation antigens with altered or deleted cytoplasmic domains. Cell 34, 535-544. 